\title{
The Determinants Of Profitability In The Pharmaceutical Industry
}

\author{
Arthur S. Leahy, William Howard Taft University, USA
}

\begin{abstract}
This paper uses several measures of profitability to examine the determinants of profitability for a segment of the U.S. pharmaceutical industry. Following Leahy (1998, 2004), I test the proposition that profitability is related to the functions performed and risks assumed by a company. As in those studies, the results vary according to the measure of profitability employed, i.e., the significance of the independent variables may depend on the profitability measure employed. These findings are consistent with those of Leahy $(1998,2004)$, which found that the results did not vary systematically according to estimation method. In addition, this paper suggests that the results vary with the industry examined.
\end{abstract}

Keywords: Pharmaceutical Profitability; Industrial Profitability; Determinates of Profitability

\section{INTRODUCTION}

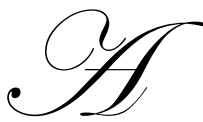

great deal of research has been done on the determinants of profitability in manufacturing (see Schmalensee, 1989). The focus of this debate has been on the appropriate measure of profitability. Most of the prior work in this area has been on inter-industry studies of profitability with the exception of Leahy (1998), which examines the profitability of distributors and Leahy (2004), which examines the profitability of liquor manufacturers. As in Leahy $(1998,2004)$ this study focuses on inter-firm determinants of profitability for a manufacturing industry, i.e., that of Standard Industrial Classification (SIC) code 2834Pharmaceutical Preparations.

In this paper, I use several measures of profitability to examine the determinants of profitability for a segment of the U.S. pharmaceutical industry. The SIC Manual (1987) defines this industry as consisting of establishments primarily engaged in manufacturing pharmaceutical preparations for human or veterinary use. This includes pharmaceutical preparations promoted primarily to the dental, medical, or veterinary professions and pharmaceutical preparations promoted primarily to the public (SIC, p. 138). Politicians and others have criticized the pharmaceutical industry by asserting that its products are overpriced and its profits excessive. ${ }^{1}$ But what determines these profits?

\section{METHODOLOGY}

Following Leahy $(1998,2004)$, I test the proposition that profitability is related to the functions performed and risks assumed by a company. Because the model developed therein provides the basis of the work that follows, a brief description of its contents is in order. Three measures of profitability are examined and related to proxies for the functions performed and/or risks assumed by those manufacturers. The three profitability measures used and their definitions are as follows:

\begin{tabular}{|c|c|c|}
\hline $\begin{array}{l}\text { Gross margin } \\
\text { Operating margin } \\
\text { Berry Ratio }\end{array}$ & 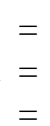 & $\begin{array}{l}\text { gross profit / sales } \\
\text { operating profit / sales } \\
\text { gross profit / operating expenses } 2\end{array}$ \\
\hline
\end{tabular}

The gross margin relates a company's gross income to its sales. Gross income reflects in part the value added by a manufacturer. The operating margin relates a company's operating income after depreciation to its sales. Operating income is a measure of the reward that a manufacturer earns for its functions. The Berry ratio relates a 
company's value added (gross margin) to the cost of providing the manufacturing function. The average values of these profitability measures are shown in Table $1 .^{3}$

Table 1

Average Values of Profit Level Indicators

\begin{tabular}{ccc}
\hline Gross Margin & Operating Margin & Berry Ratio \\
$66.3 \%$ & $33.3 \%$ & 1.08 \\
\hline
\end{tabular}

Using 2001 data for all pharmaceutical manufacturers contained in SIC code 2834 having greater than $\$ 50$ million in net sales for which all data were available from the Disclosure SEC database (as reported in the Thomson ONE Banker database), the basic model estimated is as follows: ${ }^{4}$

$\mathrm{PM}=\mathrm{b}_{0}+\mathrm{b}_{1} \mathrm{SGA} / \mathrm{SALES}+\mathrm{b}_{2} \mathrm{INV} / \mathrm{COGS}+\mathrm{b}_{3} \mathrm{AR} / \mathrm{SALES}+\mathrm{b}_{4} \mathrm{AP} / \mathrm{COGS}+\mathrm{b}_{5}$ DEP/SALES $+\mathrm{e}$

Where

PM = profitability measure, i.e., gross margin, operating margin, or Berry ratio

SGA/SALES $=$ selling and general administrative expenses $/$ net sales

INV/COGS $=$ average inventory / cost of goods sold

AR/SALES $=$ average accounts receivable $/$ net sales

AP/COGS = average accounts payable / cost of goods sold

DEP/SALES $=$ depreciation $/$ net sales

$\mathrm{e} \quad=$ an error term with mean zero and constant variance

The SGA/SALES variable is designed to capture the effect of a company's operating expenses on profitability. A manufacturer with a high ratio of operating expenses to sales expends more effort per sales dollar and is expected to earn higher profits as a result. This ratio also provides a measure of the risk assumed from the manufacturer's contractual obligations. ${ }^{5}$

The INV/COGS variable measures the impact of inventory levels with respect to cost of goods sold on profitability. This impact includes the risk associated with taking title and carrying inventory. The sign of the coefficient of this variable cannot be predicted in advance. On the one hand, higher inventory levels are a drain on profitability. On the other hand, a manufacturer with higher inventory levels is also providing a valuable function and undertaking a risk that should enhance profitability. We cannot tell in advance which of these forces is more important.

The AR/SALES variable measures the impact of a company's credit function on profitability. This impact includes the risk associated with extending credit. It is expected that the higher the ratio of accounts receivable to sales, the greater the manufacturer's profitability. Otherwise, there would be no reason for the company to provide this function.

The AP/COGS variable is designed to capture the effect of borrowing on the profitability of a company. It also measures the manufacturer's ability to negotiate the terms of purchases. The impact of this variable on profitability depends upon how the business is financed. If the manufacturer has to borrow to make up for accounts payable, then the higher the ratio of accounts payable to cost of goods sold, the lower the expected profitability. If, on the other hand, the business is financed through retained earnings, then the higher the ratio of accounts payable to cost of goods sold, the higher the expected profitability if the cost of using retained earnings is less than the cost of borrowing. We cannot tell in advance which of these forces is more important.

Lastly, the DEP/SALES variable measures the extent of depreciation with respect to sales, which the company carries. It measures the effect of differences in the costs and risks associated with the technology employed by the manufacturer on profitability. As with the INV/COGS and AP/COGS variables, the sign of the coefficient of this variable cannot be predicted in advance. The higher the level of depreciation, the higher is the cost of the company and the lower is the expected profitability. On the other hand, the greater the depreciation, the greater the risk associated with the functions performed by the manufacturer and the higher the expected profitability. 


\section{REGRESSION ANALYSIS RESULTS}

The results of the estimation of equation (1) are shown in Table 2.

Table 2

Regression Results for Pharmaceutical Manufacturers ${ }^{\text {a }}$

\begin{tabular}{|c|c|c|c|c|c|c|c|c|}
\hline Intercept & SGA/SALES & INV/COGS & AR/SALES & AP/COGS & DEP/SALES & $\mathrm{R}^{2}$ & $\mathrm{~F}$ & $\mathrm{~N}$ \\
\hline \multicolumn{9}{|c|}{ Gross Margin Results } \\
\hline $\begin{array}{l}.439^{*} \\
(5.06)\end{array}$ & $\begin{array}{c}-.000000633 \\
(.92)\end{array}$ & $\begin{array}{c}.069 \\
(1.06)\end{array}$ & $\begin{array}{c}.807 \\
(1.63)\end{array}$ & $\begin{array}{c}-.0000000725 \\
(.29)\end{array}$ & $\begin{array}{c}.523 \\
(1.32)\end{array}$ & .38 & 2.57 & 27 \\
\hline \multicolumn{9}{|c|}{ Operating Margin Results } \\
\hline $\begin{array}{l}.251 \\
(1.84)\end{array}$ & $\begin{array}{c}-.00000072 \\
(.67)\end{array}$ & $\begin{array}{c}.141 \\
(1.37)\end{array}$ & $\begin{array}{l}.318 \\
(.41)\end{array}$ & $\begin{array}{c}.0000000743 \\
(.19)\end{array}$ & $\begin{array}{l}-.926 \\
(1.48)\end{array}$ & .26 & 1.47 & 27 \\
\hline \multicolumn{9}{|c|}{ Berry Ratio Results } \\
\hline $\begin{array}{l}.516 \\
(1.92)\end{array}$ & $\begin{array}{c}-.0000014 \\
(.65)\end{array}$ & $\begin{array}{l}.707^{*} \\
(3.49)\end{array}$ & $\begin{array}{l}1.08 \\
(.70)\end{array}$ & $\begin{array}{c}-000000162 \\
(.21)\end{array}$ & $\begin{array}{l}-.705 \\
(.57)\end{array}$ & .55 & 5.14 & 27 \\
\hline
\end{tabular}

*Significant at the 1 percent level.

${ }^{* * *}$ Significant at the 5 percent level.

${ }^{a} \mathrm{t}$ statistics in parentheses.

As can be seen from Table 2, the gross margin results for pharmaceutical manufacturers show that none of the variables are significant determinants of profitability. This contrasts with the results in Leahy (2004) for liquor manufacturers which showed the coefficient of the SGA/SALES variable to have a positive and significant sign, suggesting that the expected return associated with undertaking additional functions and risk outweighs the costs associated with higher levels of selling and general administrative expenses. The coefficient of the AP/COGS was also positive and significant in this prior study. This result suggested that the effect of the additional cost associated with having greater accounts payable is outweighed by the impact of the lower cost associated with using retained earnings to finance the business.

The operating margin results for thepharmaceutical manufacturers show the coefficient of the DEP/SALES variable to be a positive and significant determinant of profitability. This result suggests that the greater risks associated with the functions performed by the manufacturer outweighs the additional costs associated with having higher depreciation. This result contrasts with those found in the operating margin equation for liquor manufacturers by Leahy (2004), in which the coefficient of the AP/COGS variable was shown to be a positive and significant determinant of profitability. This result suggested that the effect of the additional cost associated with having greater accounts payable was outweighed by the impact of the lower cost associated with using retained earnings to finance the business.

The Berry ratio results show the coefficient of the INV/COGS variable to be a positive and significant determinant of profitability. This result suggests that a manufacturer with higher inventory levels provides a valuable function and undertakes a risk that enhances profitability and that this effect outweighs the additional costs associated with higher inventory levels. This result contrasts with Leahy (2004), in which the coefficient of the AP/COGS variable was found to be a positive and significant determinant of profitability in the Berry ratio equation.

Because of significant multicollinearity between the INV/COGS variable and the AR/SALES variable ( $\mathrm{r}=.56)$, equation 1 was re-estimated with one of these variables omitted from the equation. Theses results are presented in Table 3. 
Table 3

Revised Regression Results for Pharmaceutical Manufacturers ${ }^{\mathrm{a}}$

\begin{tabular}{|c|c|c|c|c|c|c|c|c|}
\hline Intercept & SGA/SALES & INV/COGS & AR/SALES & AP/COGS & DEP/SALES & $\mathrm{R}^{2}$ & $\mathrm{~F}$ & $\mathrm{~N}$ \\
\hline \multicolumn{9}{|c|}{ Gross Margin Results } \\
\hline $\begin{array}{l}.559^{*} \\
(11.60)\end{array}$ & $\begin{array}{c}-.00000059 \\
(.83)\end{array}$ & $\begin{array}{l}.131^{* *} \\
(2.37)\end{array}$ & & $\begin{array}{c}-.00000016 \\
(.63)\end{array}$ & $\begin{array}{c}.655 \\
(1.63)\end{array}$ & .30 & 2.36 & 27 \\
\hline $\begin{array}{l}.422^{*} \\
(4.93)\end{array}$ & $\begin{array}{c}-.00000072 \\
(1.05)\end{array}$ & & $\begin{array}{l}1.11^{\text {*** }} \\
(2.75)\end{array}$ & $\begin{array}{c}-.000000047 \\
(.19)\end{array}$ & $\begin{array}{c}.447 \\
(1.14)\end{array}$ & .35 & 2.91 & 27 \\
\hline \multicolumn{9}{|c|}{ Operating Margin Results } \\
\hline $\begin{array}{l}.298^{* * *} \\
(4.16)\end{array}$ & $\begin{array}{c}-.00000071 \\
(.67)\end{array}$ & $\begin{array}{l}.165 * * \\
(2.01)\end{array}$ & & $\begin{array}{c}.0000000401 \\
(.11)\end{array}$ & $\begin{array}{c}.874 \\
(1.46)\end{array}$ & .25 & 1.86 & 27 \\
\hline $\begin{array}{l}.217 \\
(1.58)\end{array}$ & $\begin{array}{c}-.0000009 \\
(.82)\end{array}$ & & $\begin{array}{c}.932 \\
(1.44)\end{array}$ & $\begin{array}{c}.000000125 \\
(.31)\end{array}$ & $\begin{array}{l}-1.08 \\
(1.72)\end{array}$ & .19 & 1.31 & 27 \\
\hline \multicolumn{9}{|c|}{$\underline{\text { Berry Ratio Results }}$} \\
\hline $\begin{array}{l}.676^{*} \\
(4.75)\end{array}$ & $\begin{array}{c}-.0000013 \\
(.64)\end{array}$ & $\begin{array}{l}.790^{*} \\
(4.83)\end{array}$ & & $\begin{array}{c}-.00000028 \\
(.37)\end{array}$ & $\begin{array}{l}.527 \\
(.44)\end{array}$ & .54 & 6.44 & 27 \\
\hline $\begin{array}{l}.344 \\
(1.06)\end{array}$ & $\begin{array}{c}-.0000023 \\
(.88) \\
\end{array}$ & & $\begin{array}{l}4.17^{* * *} \\
(2.71)\end{array}$ & $\begin{array}{c}.0000000945 \\
(.10)\end{array}$ & $\begin{array}{c}-1.48 \\
(.99) \\
\end{array}$ & .29 & 2.23 & 27 \\
\hline
\end{tabular}

* Significant at the 1 percent level.

${ }^{* * *}$ Significant at the 5 percent level.

${ }^{a} \mathrm{t}$ statistics in parentheses.

As can be seen from Table 3, when the AR/SALES variable is omitted from the equation, INV/COGS becomes a positive and significant determinant of profitability in all of the equations. Likewise, when the INV/COGS variable is omitted from the equation, AR/SALES becomes a positive and significant determinant of profitability in all but the operating margin equation.

\section{CONCLUSION}

In this paper I have examined the determinants of profitability of pharmaceutical manufacturers. As in Leahy (1998, 2004), the results vary according to the measure of profitability employed, i.e., the significance of the independent variables may depend on the profitability measure employed. The obvious conclusion to draw about this empirical research is that these findings are consistent with those of Leahy $(1998,2004)$, which found that the results did not vary systematically according to estimation method. In addition, this paper suggests that the results vary with the industry examined.

\section{AUTHOR INFORMATION}

Dr. Arthur S. Leahy is an adjunct professor at William Howard Taft University. He is the author of over twenty publications in professional journals and books. His research interests include industrial organization and applied microeconomics. Arthur S. Leahy, William Howard Taft University, E-mail: asleahy@yahoo.com

\section{ENDNOTES}

1. William S. Comanor and Stuart O. Schweitzer, Pharmaceuticals, in The Structure of American Industry, ed. Adams and Brock, p. 177.

2. The Berry ratio was developed by Dr. Charles Berry in conjunction with the U.S. tax court case DuPont de Nemours \& Co., v. U.S. (1978). This case involved transfer pricing between a U.S. parent company and a foreign subsidiary distributor of chemicals.

3. All data are from the financial statements. 
4. While Scherer (2001) has shown that R\&D expenditures effects future profitability, it is not expected to impact current profitability. It is therefore omitted from this model.

5. It is possible that higher operating expenses may be associated with inefficiency and lead to a lower profit.

The views expressed are entirely those of the author.

\section{REFERENCES}

1. Comanor, W.S. and Stuart O. Schweitzer, Pharmaceuticals, in Adams, Walter and James Brock, ed. The Structure of American Industry, Prentice Hall, Englewood Cliffs, New Jersey, 1995.

2. E.I. DuPont de Nemours \& Co. v. United States, 78-1 U.S.T.C. (CCH) 9374 (Ct. Cl. Trial Div. 1978), aff'd, 608 F.2d 445 (Ct. Cl. 1979), cert. denied, 445 U.S. 962 (1980).

3. Executive Office of the President, Standard Industrial Classification Manual, Office of Management and Budget, 1987.

4. Leahy, A.S. Does the Choice of Profitability Measure Really Matter? The Case of Distributors, Virginia Economic Journal Vol. 3, pp. 11-15, 1998.

5. Leahy, A.S. The Determinants of Profitability in the Liquor Industry, Briefing Notes in Economics Vol. 61, pp. 1-5, 2004.

6. Scherer, F.M. The Link Between Gross Profitability and Pharmaceutical R\&D Spending, Health Affairs Vol. 20, pp. 216-20.

7. Schmalensee, R. Inter-industry Studies of Structure and Performance, in Schmalensee, R. and R.D. Willig (ed.), Handbook of Industrial Economics, Vol. II, Elsevier Science Publishers B.V., Amsterdam, 1989.

8. Thomson Analytics. Thomson ONE Banker database. 
NOTES 